A. I. Klyndyuk*, E. A. Chizhova, S. V. Shevchenko

Belarus State Technological University, 13a Sverdlova St., Minsk, 220006, Belarus Republic e-mail:klyndyuk@belstu.by

Dedicated to the memory of professor L. A. Bashkirov (1930-2020)

\title{
Spin-state transition \\ in the layered barium cobaltite derivatives and their thermoelectric properties
}

$\mathrm{Ba}_{1.9} \mathrm{Me}_{0.1} \mathrm{Co}_{9} \mathrm{O}_{14}(\mathrm{Me}=\mathrm{Ba}, \mathrm{Sr}, \mathrm{Ca})(\mathrm{BCO})$ layered cobaltites were prepared by means of solid-state reactions method. Crystal structure, microstructure, thermal expansion, electrical conductivity, and thermo-EMF for the obtained oxides were studied; the values of their linear thermal expansion coefficient, activation energy of electrical transport, and power factor values were calculated. It was found that $\mathrm{BCO}$ are $p$-type semiconductors, in which the spin-state transition occurs within 460-700 K temperature interval due to change in spin state of cobalt ions, which accompanied the sharp increase in electrical conductivity, activation energy of electrical conductivity, and linear thermal expansion coefficient, while thermo-EMF coefficient decreased. Partial substitution of barium by strontium or calcium in $\mathrm{BCO}$ leads to the increase in spin-state transition temperature and electrical conductivity of the samples, and, at the same time, thermo-EMF coefficient; consequently, their power factor values decrease.

Keywords: layered barium cobaltite; spin-state transition; thermal expansion; electrical conductivity; thermo-EMF; power factor

Received: 29.02.2020. Accepted: 20.03.2020. Published: 31.03.2020.

(C) Klyndyuk A. I., Chizhova E. A., Shevchenko S. V., 2020

\section{Introduction}

Layered sodium, calcium, or bismuthcalcium cobaltites $\left(\mathrm{Na}_{x} \mathrm{CoO}_{2}, \mathrm{Ca}_{3} \mathrm{Co}_{4} \mathrm{O}_{9}\right.$, $\mathrm{Bi}_{2} \mathrm{Ca}_{2} \mathrm{Co}_{1.7} \mathrm{O}_{x}$ ) are prospective materials for producing of $p$-branches for high-temperature thermoelectric generators, since they possess high values of electrical conductivity $(\sigma)$ and thermo-EMF coefficient $(S)$ and low thermal conductivity $(\lambda)$, as well as high stability at elevated temperatures in air [1-4]. The common elements of crystal structure, which are present in all of these compounds, are the conducting $\left[\mathrm{CoO}_{2}\right]$ layers.
Layered barium cobaltite $\mathrm{Ba}_{2} \mathrm{Co}_{9} \mathrm{O}_{14}$, which belongs to the $\mathrm{Ba}_{2 n+1} \mathrm{Co}_{n} \mathrm{O}_{3 n+3}\left(\mathrm{Co}_{8} \mathrm{O}_{8}\right)$ series [5], was also tested recently as a possible thermoelectric oxide [6]. Crystal structure of $\mathrm{Ba}_{2} \mathrm{Co}_{9} \mathrm{O}_{14}$ consists of alternated $\left[\mathrm{CoO}_{2}\right]$ layers $\left(\mathrm{CdI}_{2}\right.$-type) and octahedral trimers $\mathrm{Co}_{3} \mathrm{O}_{12}$ that are interconnected by cornershared $\mathrm{CoO}_{4}$ tetrahedra [6]. $\mathrm{Ba}_{2} \mathrm{Co}_{9} \mathrm{O}_{14}$ crystallizes in the rhombohedral syngony (space group $R \overline{3} m, Z=3$ ) with the unit cell parameters: $a=5.6958(4) \AA, c=28.909(4) \AA$ [6], $a=5.6963(8) \AA ̊ ., c=28.924(6) \AA$ [7], 
$a=5.69464(3) \AA, c=28.9017(2) \AA ̊[8]$. Layered barium cobaltite is stable in air up to $1303 \mathrm{~K}$; it decomposes to $\mathrm{CoO}$ and $\mathrm{Ba}-$ $\mathrm{CoO}_{2}$ at higher temperatures [7].

It was reported that at room temperature $\mathrm{Ba}_{2} \mathrm{Co}_{9} \mathrm{O}_{14}$ is paramagnetic $\left(T_{N}=39 \mathrm{~K}\right.$ [7], $\approx 40 \mathrm{~K}[8])$; its resistivity was evaluated as $\rho_{300}>2 \Omega \cdot \mathrm{cm}[7]$, or $20 \Omega \cdot \mathrm{cm}[8,9]$. The main charge carriers in $\mathrm{Ba}_{2} \mathrm{Co}_{9} \mathrm{O}_{14}$ are electronic holes [6,7], so, similar to the other layered cobaltites, it is a $p$-type conductor [1-4]. Electrical conductivity of layered barium cobaltite sharply increases within the temperature range of 473-673 K [7] due to the spin-state transition of $\mathrm{Co}^{3+}$ ions inside the $\mathrm{Co}_{3} \mathrm{O}_{12}$ octahedral trimers from low spin-state (LS) into high spin-state (HS) near $570 \mathrm{~K}$ (spin-state transition) [8, 10]. Studying of magnetic, electrotransport, and thermoelectric properties of $\mathrm{Ba}_{1.9} \mathrm{M}_{0.1} \mathrm{Co}_{9} \mathrm{O}_{14}$ $(\mathrm{M}=\mathrm{Ba}, \mathrm{La}, \mathrm{Na})$ materials below room tem-

\section{Experimental}

Ceramic samples of the $\mathrm{Ba}_{1.9} \mathrm{M}_{0.1} \mathrm{Co}_{9} \mathrm{O}_{14}$ $(\mathrm{M}=\mathrm{Ba}, \mathrm{Sr}, \mathrm{Ca})$ composition have been prepared using solid-state reaction method from mixtures of starting materials $\mathrm{BaCO}_{3}$, $\mathrm{SrCO}_{3}, \mathrm{CaCO}_{3}, \mathrm{Co}_{3} \mathrm{O}_{4}(99.0 \%)$, taken in appropriate stoichiometric compositions, in air within the temperature range $1173-1273 \mathrm{~K}$ during $40 \mathrm{~h}$ with few intermediate grindings according to the method described earlier [13].

Samples' phase identification and determination of their unit cell parameters were performed using X-ray diffraction analysis (XRD) with a Bruker D8 Advance diffractometer ( $\mathrm{Cu}$ Ka radiation, Ni filter). The microstructure of sintered ceramics was studied by means of a JSM - 5610 LV scanning electron microscope (JEOL, Japan). Relative density $\left(\rho_{\text {rel }}\right)$ of the sintered ceramic samples was calculated as

$$
\rho_{\text {rel }}=\left(\rho_{a p p} / \rho_{X R D}\right) \cdot 100 \% \text {, }
$$

perature [9] allows us to conclude that they are $p$-type polaronic conductors; however, the values of their figure-of-merit are too small $\left(Z T=S^{2} \cdot \sigma \cdot T / \lambda<<1\right)$ to consider them as potential thermoelectric materials for low-temperature applications (at $T<300 \mathrm{~K}$ ).

It was also reported $[11,12]$ that $\mathrm{Ba}_{2} \mathrm{Co}_{9} \mathrm{O}_{14}$ can be used as a cathode material for intermediate-temperature solid oxide fuel cells in contact with various electrolytes, such as yttria stabilized zirconia (YSZ) or cerium doped gadolinium oxide (GCO).

The aim of this work was to study the effect of partial substitution of barium by strontium or calcium in $\mathrm{Ba}_{2} \mathrm{Co}_{9} \mathrm{O}_{14}$ on crystal structure, microstructure, thermal expansion, electrotransport and thermoelectric properties of layered barium cobaltite derivatives above room temperature.

where $\rho_{a p p}$ is apparent density, determined from the mass and dimensions of the samples; $\rho_{X R D}$ is calculated X-ray density.

Thermal expansion, electrical conductivity and thermo-EMF of the samples were measured within $300-1100 \mathrm{~K}$ in air according to the methods described in detail elsewhere [13-15]. Values of average linear thermal expansion coefficient (LTEC, $\alpha_{a v}$ ), activation energy of electrical conductivity $\left(E_{A, a v}\right)$ and thermo-EMF $\left(E_{S, a v}\right)$ were calculated from the linear parts of $\Delta l / l_{0}=f(T)$, $\ln (\sigma \cdot T)=f(1 / T)$, and $S=f(1 / T)$ plots, respectively. The true values of LTEC $(\alpha)$ and activation energy for electrical conductivity $\left(E_{A}\right)$ were calculated as follows:

$$
\begin{gathered}
\alpha=\mathrm{d}\left(\Delta l / l_{0}\right) / \mathrm{d} T, \\
E_{A}=(R / F) \cdot \mathrm{d} \ln \rho / \mathrm{d}(1 / T),
\end{gathered}
$$

where $R$ is gas constant, $F$ is Faraday constant, $\rho$ is the electrical resistivity of the sample. 
Power factor values for the ceramics studied were found using equation

\section{Results and discussion}

All the BCO samples after the final stage of annealing were found to be single phase within XRD accuracy; they possessed structure of layered barium cobaltite with unit cell parameters $a \approx 5.7 \AA, c \approx 29.0 \AA$ (Table 1 ). The obtained values are in good agreement within the experimental error with the data given in the literature [6-9]. The unit cell parameters for $\mathrm{Ba}_{1.9} \mathrm{M}_{0.1} \mathrm{Co}_{9} \mathrm{O}_{14}$ $(\mathrm{M}=\mathrm{Sr}, \mathrm{Ca})$ solid solutions do not differ much from those reported for undoped $\mathrm{Ba}_{2} \mathrm{Co}_{9} \mathrm{O}_{14}$ (Table 1), despite of the large difference in ionic radii between dopants and barium (for coordination number of 6 $R_{\mathrm{Ba}^{2+}}=1.36 \AA, R_{\mathrm{Sr}^{2+}}=1.16 \AA, R_{\mathrm{Ca}^{2+}}=1.00 \AA$ [16]), which is probably due to the small substitution degree of strontium or calcium $(x=0.1)$ in these solid solutions.

The values of relative density of the $\mathrm{Ba}_{1.9} \mathrm{M}_{0.1} \mathrm{Co}_{9} \mathrm{O}_{14}$ ceramics were equal to $75 \%, 68 \%$, and $66 \%$ for $\mathrm{M}=\mathrm{Ba}, \mathrm{Sr}$, and $\mathrm{Ca}$, respectively. This fact let us to conclude that partial isovalent substitution

$$
P=S^{2} \cdot \sigma
$$

of barium by other alkaline-earth elements in $\mathrm{Ba}_{2} \mathrm{Co}_{9} \mathrm{O}_{14}$ essentially decreases its sinterability.

Crystallites of BCO ceramics had a plate-like form, which is typical for ceramics of layered cobaltites; their sizes varied within $2-5 \mu \mathrm{m}$ and the thickness changed within $0.5-1 \mu \mathrm{m}$ (Fig. 1).

The temperature dependences of relative elongation of the studied samples demonstrate three obvious regions (Fig. 2,

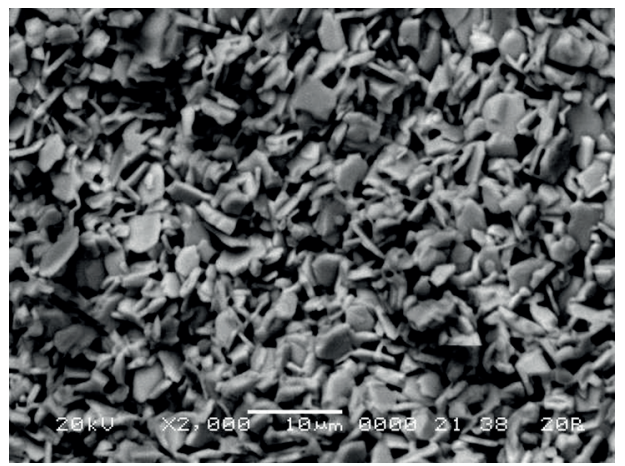

Fig. 1. Electron microscopy image of the $\mathrm{Ba}_{1.9} \mathrm{Sr}_{0.1} \mathrm{Co}_{9} \mathrm{O}_{14}$ ceramics surface

Table 1

The unit cell parameters for the $\mathrm{Ba}_{1.9} \mathrm{M}_{0.1} \mathrm{Co}_{9} \mathrm{O}_{14}$ cobaltites

\begin{tabular}{c|c|c|c|c}
\hline $\mathrm{M}$ & $a, \AA$ & $c, \AA$ & $c / a$ & $V, \AA^{3}$ \\
\hline $\mathrm{Ba}$ & $5.697 \pm 0.006$ & $28.97 \pm 0.09$ & $5.09 \pm 0.02$ & $814.4 \pm 4.1$ \\
\hline $\mathrm{Sr}$ & $5.696 \pm 0.007$ & $28.98 \pm 0.11$ & $5.09 \pm 0.02$ & $814.4 \pm 4.9$ \\
\hline $\mathrm{Ca}$ & $5.703 \pm 0.005$ & $29.03 \pm 0.07$ & $5.09 \pm 0.02$ & $817.7 \pm 3.2$ \\
\hline
\end{tabular}

Table 2

Average values of LTEC $\left(\alpha_{a v}\right)$ for the sintered $\mathrm{Ba}_{1.9} \mathrm{M}_{0.1} \mathrm{Co}_{9} \mathrm{O}_{14}$ ceramics

\begin{tabular}{c|c|c|c|c|c}
\hline \multirow{2}{*}{$\mathrm{M}$} & \multicolumn{3}{|c|}{$\alpha_{a v}, \mathrm{ppm} / \mathrm{K}$} & \multirow{2}{*}{$T_{1}, \mathrm{~K}$} & \multirow{2}{*}{$T_{2}, \mathrm{~K}$} \\
\cline { 2 - 4 } & $300-T_{1}$ & $T_{1}-T_{2}$ & $T_{2}-1000$ & & \\
\hline $\mathrm{Ba}$ & $10.9 \pm 0.7$ & $36.6 \pm 0.5$ & $21.3 \pm 0.2$ & 475 & 650 \\
\hline $\mathrm{Sr}$ & $13.9 \pm 0.6$ & $43.9 \pm 1.1$ & $19.7 \pm 0.2$ & 500 & 640 \\
\hline $\mathrm{Ca}$ & $17.3 \pm 0.5$ & $28.1 \pm 0.2$ & $21.7 \pm 0.1$ & 500 & 700 \\
\hline
\end{tabular}


Table 2); the second one characterized by larger values of LTEC, corresponded to the broad spin-state transition of cobalt ions from low spin-state into high spinstate inside $\mathrm{Co}_{3} \mathrm{O}_{12}$ trimers in the crystal structure $[8,10]$. Partial substitution of barium by strontium or calcium in $\mathrm{Ba}_{2} \mathrm{Co}_{9} \mathrm{O}_{14}$ raises $\alpha_{a v}$ values in the first region (before spin-state transition). This is caused by the increase in anharmonicity degree of metal-oxygen vibrations in the lattice, and resulted in the shift of the spin-state transition to the higher temperatures ( $\mathrm{Ta}$ ble 2, Fig. 2, light-gray rectangle area). The temperature of $\mathrm{Co}^{3+}(\mathrm{LS}) \rightarrow \mathrm{Co}^{3+}(\mathrm{HS})$ transition, which was determined as a peak temperature on the $a=f(T)$ dependences for the materials studied, was equal to $560 \mathrm{~K}, 575 \mathrm{~K}$, and $600 \mathrm{~K}$ for $\mathrm{Ba}_{2} \mathrm{Co}_{9} \mathrm{O}_{14}$, $\mathrm{Ba}_{1.9} \mathrm{Sr}_{0.1} \mathrm{Co}_{9} \mathrm{O}_{14}$, and $\mathrm{Ba}_{1.9} \mathrm{Ca}_{0.1} \mathrm{Co}_{9} \mathrm{O}_{14}$, respectively (Fig. 2, insets). The values of $\alpha_{a v}$ in the third region of the $\Delta l / l_{0}=f(T)$ dependences $\left(T>T_{2}\right)$ were essentially larger compared to those in the first one $\left(T<T_{1}\right)$. The latter was caused by destroying of charge-ordered state of $\mathrm{Co}^{2+} / \mathrm{Co}^{3+}$ ions in the $\mathrm{CoO}_{2}$ layers after the spin-state transition in the layered barium cobaltite had completed [8]. It is worth noting that similar shape of $\Delta l / l_{0}=f(T)$ dependences was observed by us earlier for $\mathrm{Nd}_{1-x} \mathrm{Gd}_{x} \mathrm{CoO}_{3}$ solid solutions in which a semiconductor-metal phase transition took place within the temperature range 370-790 K due to the spin-state transition of $\mathrm{Co}^{3+}$ ions from the low spin-state to the intermediate spin-state (IS) [17].

$$
\mathrm{Ba}_{1.9} \mathrm{M}_{0.1} \mathrm{Co}_{9} \mathrm{O}_{14}(\mathrm{M}=\mathrm{Ba}, \mathrm{Sr}, \mathrm{Ca}) \text { com- }
$$
pounds were $p$-type semiconductors (Fig. 2), which is in good agreement with the results of $[5,7-9]$. The values of electrical conductivity sharply (by more than two orders of magnitude) increased within 460-665 K temperature interval, which was accompanied by essential (up to three-five times) decrease in the Seebeck coefficient (Fig. 2) due to the change in spin state of cobalt ions $\mathrm{Co}^{3+}(\mathrm{LS}) \rightarrow \mathrm{Co}^{3+}(\mathrm{HS})$
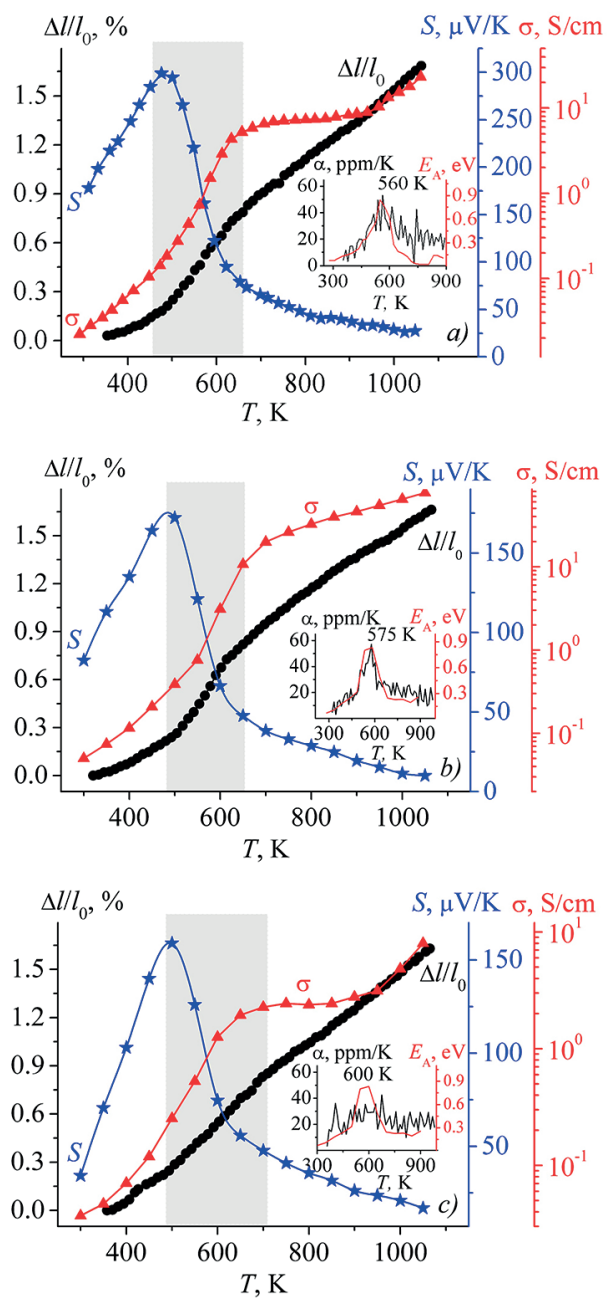

Fig. 2. Temperature dependences of relative elongation $\left(\Delta l / l_{0}\right)$, electrical conductivity

$(\sigma)$, and thermo-EMF coefficient $(S)$ for $\mathrm{Ba}_{2} \mathrm{Co}_{9} \mathrm{O}_{14}(a), \mathrm{Ba}_{1.9} \mathrm{Sr}_{0.1} \mathrm{Co}_{9} \mathrm{O}_{14}(b)$, and $\mathrm{Ba}_{1.9} \mathrm{Ca}_{0.1} \mathrm{Co}_{9} \mathrm{O}_{14}(c)$. Insets show the temperature dependences of true values for LTEC ( $\alpha$ ) and for electrical conductivity activation energy $\left(E_{A}\right)$. Light-gray rectangle area shows the temperature interval $\left(T_{1}-T_{2}\right)$, in which the spin-state transition of $\mathrm{Co}^{3+}$ ions takes place 
(spin-state transition) inside $\mathrm{Co}_{3} \mathrm{O}_{12}$ trimers $[8,10]$. We have observed earlier $[17,18]$ similar behavior of $\sigma=f(T)$ and $S=f(T)$ dependences for the $\mathrm{Nd}_{1-x} \mathrm{Gd}_{x-}$ $\mathrm{CoO}_{3}, \mathrm{LnCo}_{1-x} \mathrm{Ga}_{x} \mathrm{CoO}_{3}(\mathrm{Ln}=\mathrm{La}, \mathrm{Nd})$ solid solutions, in which semiconductormetal phase transitions occur within temperature intervals of $325-860 \mathrm{~K}$ and 550$950 \mathrm{~K}$, respectively, due to change of spin state of $\mathrm{Co}^{3+}$ ions form the low spin-state to the intermediate spin-state. The temperatures of spin-state transition, which were determined as peak temperatures on the $E_{A}=f(T)$ dependences for the cobaltites studied, were equal to $560 \mathrm{~K}, 575 \mathrm{~K}$, and $600 \mathrm{~K}$ for $\mathrm{Ba}_{2} \mathrm{Co}_{9} \mathrm{O}_{14}, \mathrm{Ba}_{1.9} \mathrm{Sr}_{0.1} \mathrm{Co}_{9} \mathrm{O}_{14}$, and $\mathrm{Ba}_{1.9} \mathrm{Ca}_{0.1} \mathrm{Co}_{9} \mathrm{O}_{14}$, respectively (Fig. 2, insets); they coincided with those found from the dilatometry results. The values of room temperature electrical conductivity in BCO ceramics increase when barium is partially substituted by strontium or calcium. $\mathrm{Ba}_{1.9} \mathrm{Sr}_{0.1} \mathrm{Co}_{9} \mathrm{O}_{14}$ solid solution reveals highest conductivity within entire temperature interval studied (Fig. 2).

The average values of electrical conductivity activation energy for the BCO ceramics were maximal within the middle temperature $\left(T_{1}-T_{2}\right)$ region (Fig. 3, Table 3) where spin-state transition took place. At the same time, average $E_{\mathrm{A}}$ values for the $\mathrm{Ba}_{1.9} \mathrm{M}_{0.1} \mathrm{Co}_{9} \mathrm{O}_{14}(\mathrm{M}=\mathrm{Sr}$, $\mathrm{Ca})$ solid solutions within the high temperature region $\left(T_{2}-1000 \mathrm{~K}\right)$ were larger than those at low temperatures $\left(300 \mathrm{~K}-T_{1}\right)$, which is in good agreement with the results obtained earlier [7, 8]. Thermo-EMF values for the $\mathrm{Ba}_{1.9} \mathrm{M}_{0.1} \mathrm{Co}_{9} \mathrm{O}_{14}(\mathrm{M}=\mathrm{Sr}, \mathrm{Ca})$ solid solutions were smaller than those for $\mathrm{Ba}_{2} \mathrm{Co}_{9} \mathrm{O}_{14}$ cobaltite, especially in the vicinity of room temperature (Fig. 2). The shape of the $\sigma=f(T)$ and $S=f(T)$ dependences for BCO ceramics as well as the fact that $E_{S, a v}<E_{A, a v}$ let us conclude that charge carriers in the studied materials can be described by the small polaron model [19].

The shape of power factor temperature dependences for the studied compounds were similar to that of the $S=f(T)$ curves (Fig. 2, 4). The maximum on the $P=f(T)$ dependence for the $\mathrm{Ba}_{1.9} \mathrm{Sr}_{0.1} \mathrm{Co}_{9} \mathrm{O}_{14}$ solu-

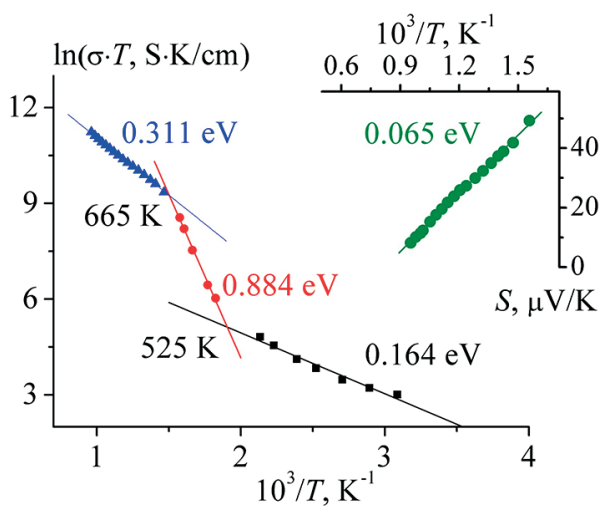

Fig. 3. Dependences of $\ln (\sigma \cdot T)=f(1 / T)$ and $S=f(1 / T)$ for $\mathrm{Ba}_{1.9} \mathrm{Sr}_{0.1} \mathrm{Co}_{9} \mathrm{O}_{14}$.

The average values for electrical conductivity activation energy $\left(E_{A, a v}\right)$ and thermo-EMF activation energy $\left(E_{S, a v}\right)$ are given near the corresponding lines

Table 3

Values of average activation energy of electrical conductivity $\left(E_{A, a v}\right)$ and thermo-EMF $\left(E_{S, a v}\right)$ of $\mathrm{Ba}_{1.9} \mathrm{M}_{0.1} \mathrm{Co}_{9} \mathrm{O}_{14}$ cobaltites

\begin{tabular}{c|c|c|c|c|c|c}
\hline \multirow{2}{*}{$\mathrm{M}$} & \multicolumn{3}{|c|}{$E_{A, a v}, \mathrm{eV}$} & \multirow{2}{*}{$T_{1}, \mathrm{~K}$} & \multirow{2}{*}{$T_{2}, \mathrm{~K}$} & \multirow{2}{*}{$E_{S, a v}, \mathrm{eV}$} \\
\cline { 2 - 4 } & $300-T_{1}$ & $T_{1}-T_{2}$ & $T_{2}-1000$ & & & \\
\hline $\mathrm{Ba}$ & $0.166 \pm 0.011$ & $0.711 \pm 0.035$ & $0.143 \pm 0.006$ & 495 & 650 & $0.083 \pm 0.003$ \\
\hline $\mathrm{Sr}$ & $0.164 \pm 0.012$ & $0.884 \pm 0.032$ & $0.311 \pm 0.003$ & 525 & 665 & $0.065 \pm 0.001$ \\
\hline $\mathrm{Ca}$ & $0.119 \pm 0.012$ & $0.470 \pm 0.020$ & $0.128 \pm 0.008$ & 460 & 640 & $0.058 \pm 0.001$ \\
\hline
\end{tabular}


tion was shifted towards the larger temperature, while that for $\mathrm{Ba}_{1.9} \mathrm{Ca}_{0.1} \mathrm{Co}_{9} \mathrm{O}_{14}$ was shifted down to smaller temperature, as compared to the $\mathrm{Ba}_{2} \mathrm{Co}_{9} \mathrm{O}_{14}$ parent phase. The maximal value of power factor obtained for the $\mathrm{Ba}_{2} \mathrm{Co}_{9} \mathrm{O}_{14}$ cobaltite was equal to $3.36 \mu \mathrm{W} /\left(\mathrm{m} \cdot \mathrm{K}^{2}\right)$ at $600 \mathrm{~K}$; all $P$ values of this phase within the entire temperature interval studied were larger than those for the $\mathrm{Ba}_{1.9} \mathrm{M}_{0.1} \mathrm{Co}_{9} \mathrm{O}_{14}(\mathrm{M}=\mathrm{Sr}, \mathrm{Ca})$ solid solutions, except the temperature interval 700 $950 \mathrm{~K}$, in which $\mathrm{Ba}_{1.9} \mathrm{Sr}_{0.1} \mathrm{Co}_{9} \mathrm{O}_{14}$ possessed maximal of the power factor values, mainly due to the fact that its Seebeck coefficient was essentially smaller in comparison with unsubstituted $\mathrm{Ba}_{2} \mathrm{Co}_{9} \mathrm{O}_{14}$ phase.

Although the power factor values for the layered barium cobaltite ceramics synthesized in this work are too small to consider these oxide materials prepared using conventional solid-state reactions method

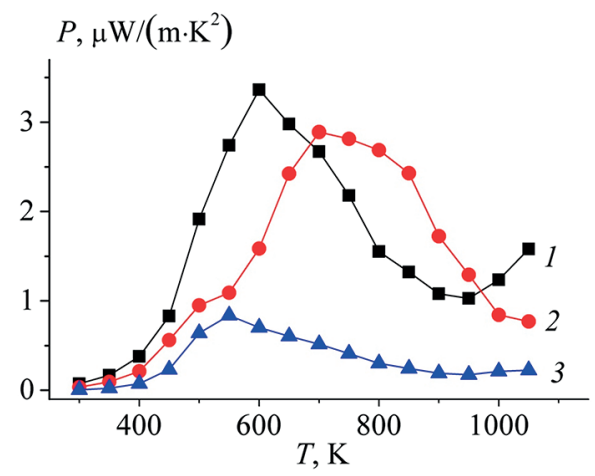

Fig. 4. Temperature dependences of power factor $(P)$ for $\mathrm{Ba}_{1.9} \mathrm{M}_{0.1} \mathrm{Co}_{9} \mathrm{O}_{14}$ compounds: $\mathrm{M}=\mathrm{Ba}(1), \mathrm{Sr}(2)$, and $\mathrm{Ca}(3)$

as possible high-temperature thermoelectrics, they can be improved using special sintering methods (spark plasma sintering, hot pressing etc.), which can help to obtain low-porous textured ceramics with essentially larger values of electrical conductivity and, consequently, higher power factors.

\section{Conclusions}

The ceramic samples of $\mathrm{Ba}_{2} \mathrm{Co}_{9} \mathrm{O}_{14}$ and its derivatives $\mathrm{Ba}_{1.9} \mathrm{Me}_{0.1} \mathrm{Co}_{9} \mathrm{O}_{14}(\mathrm{Ba}, \mathrm{Sr}, \mathrm{Ca})$ were prepared using solid-state reactions method. The values of unit cell parameters and microstructure, thermal expansion, electrotransport and thermoelectric properties were determined. It was shown that synthesized materials are $p$-type semiconductors, in which the spin-state transition occurs within 460-700 K temperature interval that caused by change of spin state of cobalt ions. It was accompanied with sharp increase in electrical conductivity value, activation energy of electrical conductivity, and linear thermal expansion coefficient, while the Seebeck coefficient decreased. It was found that partial substitution of barium by strontium or calcium in $\mathrm{Ba}_{2} \mathrm{Co}_{9} \mathrm{O}_{14}$ leads to the increase of spinstate transition temperature and electrical conductivity of the oxides, while thermoEMF coefficient and power factor values were decreased.

\section{Acknowledgements}

This work was carried out in the frame of State Program of Scientific Investigations «Physical materials science, new materials and technologies» (subprogram «Materials science and technologies of materials», task 1.55). 


\section{References}

1. Terasaki I, Sasago Y, Uchinokura K. Large thermoelectric power in $\mathrm{NaCo}_{2} \mathrm{O}_{4}$ single crystals. Phys Rev B. 1997;56(20):R12685-7.

DOI: 10.1103/PhysRevB.56.R12685

2. Krasutskaya NS, Klyndyuk Aim Evseeva LE, Tanaeva SA. Synthesis and Properties of $\mathrm{Na}_{x} \mathrm{CoO}_{2}(x=0.55,0.89)$ Oxide Thermoelectrics. Inorg Mater. 2016;52(4):393-9. DOI: $10.1134 /$ S0020168516030079

3. Masset AC, Michel C, Maignan A, Hervieu M, Toulemonde O, Studer F, Raveau B, Hejtmanek. J. Misfit-Layered Cobaltite with an Anisotropic Giant Magnetoresistance: $\mathrm{Ca}_{3} \mathrm{Co}_{4} \mathrm{O}_{9}$. Phys Rev B. 2000;62(1):166-75.

DOI: 10.1103/PhysRevB.62.166

4. Sotelo A, Rasekh Sh, Madre MA, Guilmeau E, Marinel S, Diez JC. Solution-based synthesis routes to thermoelectric $\mathrm{Bi}_{2} \mathrm{Ca}_{2} \mathrm{Co}_{1.7} \mathrm{O}_{x}$. J Eur Ceram Soc. 2011;31(9):1763-9. DOI: 10.1016/j.jeurceramsoc.2011.03.008

5. Sun J, Yang M, Guobao L, Yang T, Liao F, Wang Y, Xiong M, Lin J. New Barium Cobaltite Series $\mathrm{Ba}_{n+1} \mathrm{Co}_{n} \mathrm{O}_{3 n+3}\left(\mathrm{Co}_{8} \mathrm{O}_{8}\right)$ : Intergrowth Structure Containing Perovskite and $\mathrm{CdI}_{2}$-Type Layers. Inorg Chem. 2006;45(23):9151-3.

DOI: $10.1021 /$ ic060992v

6. Delorme F, Chen C, Pignon B, Schoenstein F, Perriere L, Giovannelli F. Promising high temperature thermoelectric properties of dense $\mathrm{Ba}_{2} \mathrm{Co}_{9} \mathrm{O}_{14}$ ceramics. J Eur Ceram Soc. 2017;37(7):2615-20.

DOI: 10.1016/j.jeurceramsoc.2017.01.034

7. Ehora G, Daviero-Minaud S, Colmont M, Andre G., Mentre O. $\mathrm{Ba}_{2} \mathrm{Co}_{9} \mathrm{O}_{14}$ : New Inorganic Building Blocks with Magnetic Odrering through Super-Super Exchanges Only. Chem Mater. 2007;19:2180-8.

DOI: $10.1021 / \mathrm{cm} 062987 \mathrm{q}$

8. Cheng JG, Zhou JS, Hu Z, Suchomel MR, Chin YY, Kuo CY, Lin HJ, Chen JM, Pi DW, Chen CT, Takami T, Tjeng LH, Goodenough JB. Spin-state transition in $\mathrm{Ba}_{2} \mathrm{Co}_{9} \mathrm{O}_{14}$. Phys Rev B. 2012;85:094424.

DOI: 10.1103/PhysRevB.85.094424

9. Takami T, Saiki S, Cheng J, Goodenough JB. Magnetic and Transport Properties of $\mathrm{Ba}_{2} \mathrm{Co}_{9} \mathrm{O}_{14}$ and $\mathrm{Ba}_{1.9} \mathrm{~A}_{0.1} \mathrm{Co}_{9} \mathrm{O}_{14}(\mathrm{~A}=\mathrm{La}$ or Na). J Phys Soc Jap. 2010;79(11):114713. DOI: 10.1143/JPSJ.79.114713

10. Zagrioui M, Delorme F, Chen C, Camara NR, Giovannelli F. Raman study of high temperature insulator-insulator transition in $\mathrm{Ba}_{2} \mathrm{Co}_{9} \mathrm{O}_{14}$. Solid State Sci. 2018;79:1-5. DOI: $10.1016 /$ j.solidstatesciences.2018.03.003

11. Rolle A, Preux N, Ehora G, Mentre O, Daviero-Minaud S. Potentiality of $\mathrm{Ba}_{2} \mathrm{Co}_{9} \mathrm{O}_{14}$ as cathode material for IT-SOFC on various electrolytes. Solid State Ionics. 2011;184:31-4.

DOI: $10.1016 / j . s s i .2010 .10 .016$

12. Li Y, Xu MW, Goodenough JB. Electrochemical performance of $\mathrm{Ba}_{2} \mathrm{Co}_{9} \mathrm{O}_{14}+\mathrm{SDC}$ composite cathode for intermediate-temperature solid oxide fuel cells. J Power Sources. 2012;209:40-3.

DOI: $10.1016 /$ j.jposour.2012.02.034 
13. Matsukevich IV, Klyndyuk AI, Tugova EA, Tomkovich MV, Krasutskaya NS, Gusarov VV. Synthesis and Properties of Materials Based on Layered Calcium and Bismuth Cobaltites. Rus J Appl Chem. 2015;88(8):1241-7.

DOI: $10.1134 /$ S1070427215080030

14. Klyndyuk AI, Chizhova EA. Structure, Thermal Expansion, and Electrical Properties of $\mathrm{BiFeO}_{3}-\mathrm{NdMnO}_{3}$ Solid Solutions. Inorg Mater. 2015;51(3):272-7.

DOI: 10.1134/S0020168515020090

15. Klyndyuk AI, Petrov GS, Poluyan AF, Bashkirov LA. Structure and Physicochemical Properties of $\mathrm{Y}_{2} \mathrm{Ba}_{1-x} \mathrm{M}_{x} \mathrm{CuO}_{5}(\mathrm{M}=\mathrm{Sr}, \mathrm{Ca})$ Solid Solutions. Inorg Mater. 1999;35(5):512-6.

16. Shannon RD. Revised effective ionic radii and systematic studies of interatomic distances in halides and chalcogenides. Acta Cryst. 1976;A32:751-67.

DOI: $10.1107 /$ S0567739476001551

17. Kurgan SV, Petrov GS, Bashkirov LA, Klyndyuk AI. Properties of $\mathrm{Nd}_{1-x} \mathrm{Gd}_{x} \mathrm{CoO}_{3}$ Solid Solutions. Inorg. Mater. 2004;40(11):1224-8.

18. Lubinsky NN, Bashkirov LA, Petrov GS, Klyndyuk AI. Thermo-EMF and Electric Conductivity of Lanthanum and Neodymium Cobaltites - Gallates Solid Solutions. J Thermoelectricity. 2009;(1):47-54.

19. Mott NF, Davis EA. Electronic Processes in Non-Crystalline Materials. $2^{\text {nd }}$ ed. New York, USA: Oxford University Press; 1979. 605 p. 